\section{Expanding the kinase kingdom}

\section{By Brian Moy, Staff Writer}

Researchers at Harvard Medical School, the Dana-Farber Cancer Institute and Brigham and Women's Hospital have applied loss-offunction small hairpin RNA screens to various human cell lines to identify kinases that are essential for cell proliferation and survival. ${ }^{1-4}$ The approach could substantially expand the number of kinases targeted in cancer.

Loss-of-function shRNA screens are often used to investigate various cell biological processes, such as NF- $\mathrm{KB}$ signal transduction, proteasome function, p53 signal transduction, modulation of RAS function, modulation of mitosis and mammary cell transformation. ${ }^{5-10}$

In a quartet of papers published in the Proceedings of the National Academy of Sciences, the team used shRNA screens to identify functional differences in essential kinases across a variety of human cancer cell lines from different tissues. According to Edward Harlow, chairman of the Department of Biological
"By screening specific tumor cells for kinases that are required for viability, we are able to identify interesting targets that have strong lethal phenotypes and display preferential killing of one cell type over another."

- Edward Harlow,

Harvard Medical School
In the third paper, the researchers found that isogenic renal carcinoma cells lacking the von Hippel-Lindau tumor suppressor (VHL) gene were more sensitive to the loss of the CDK6, MET and MAP2K1 kinases than wild-type cells expressing the VHL gene product, pVHL. ${ }^{3}$

The final paper identified 10 kinases that were required in the cervical carcinoma cell line HeLa but not in the renal carcinoma cell line

Kinase in the hole

Harlow told SciBX that "the screening platform sets the stage for identifying kinases that could be novel targets for drug discovery. By screening specific tumor cells for kinases that are required for viability, we are able to identify interesting targets that have strong lethal phenotypes and display preferential killing of one cell type over another."

He estimated that there are more than 650 known kinases, of which only about 30 have been pursued as potential drug targets. "Although many of the kinases we identified are already being studied, we did identify several that have not been studied in any detail," said Harlow, who declined to elaborate.

Patrick Zarrinkar, VP of technology development at Ambit Biosciences Corp., agreed with Harlow.

"There are a relatively small number of kinases being pursued," he said. "The PNAS papers not only suggest that a greater diversity of kinases should be explored as potential therapeutic targets, but also provide a way to Chemistry and Molecular Pharmacology at Harvard Medical School and corresponding author of the PNAS papers, the loss-of-function screens used in the studies are the first to have been performed across such a large number of tumor cell lines.

The screens also were used to detect differences in kinase requirements between closely related cells that differ only by expression of a single oncogene or tumor suppressor gene.

In the first paper, application of shRNA loss-of-function screens to various mammalian tissue and cell cultures indicated that kinase requirements for proliferation and survival vary substantially from one cell line to another. For example, in a cervical carcinoma cell line and in a line of human kidney epithelial cells transformed by DNA virus oncoproteins, 89 shRNAs blocked cell proliferation and survival by at least $50 \%$ in either cell line. However, only 20 of the shRNAs were common to both lines.

The second paper detailed how expression of the HPV16 E7 oncoprotein in the RKO colon carcinoma cell line can change the patterns of kinase requirements. The results of the loss-of-function screen identified several kinases, including CDK6, ERBB3, FYN, AAK1 and TSSK2, that were required for the survival of normal RKO cells but not for RKO cells expressing the human papillomavirus oncoprotein. ${ }^{2}$ generate promising hypotheses as to which kinases might be good targets for treating specific cancers."

Ambit markets its KinomeScan profiling technology, a high throughput screen to evaluate, analyze and test compound libraries against kinase targets. "With KinomeScan, we are able to screen a library of compounds against a panel of kinases and subsequently choose which kinase targets to more aggressively pursue based on what kinase inhibitors are available," Zarrinkar said.

Ambit's lead compound is AC220, an FMS-like tyrosine kinase 3 (FLT3) inhibitor in Phase I testing to treat acute myelogenous leukemia (AML).

Axel Ullrich, director of the Department of Molecular Biology at the Max Planck Institute of Biochemistry, was less sanguine. He noted that technologies such as gene expression array chips and comparative genomic hybridization have been unable to generate significant breakthroughs in target identification.

Ullrich told SciBX that cancer is simply too heterogeneous, and as a result he does "not see potential in target identification with this technology." teomics discovery company Kinaxo Biotechnologies GmbH, cancer
Ullrich is the founder of several biotech companies, including pro- 


\section{DRUG PLATFORMS}

antibody specialist U3 Pharma AG, kinase discovery company Axxima Pharmaceuticals AG and cancer company Sugen Inc.

The latter three were acquired by Daiichi Sankyo Co. Ltd., GPC Biotech AG and Pharmacia Corp. (now Pfizer Inc.), respectively.

Harlow said further studies will flesh out "whether the kinases we identified will be good targets in their own right."

Harlow and colleagues are using the screening platform to further investigate the biology behind cancer cell requirements as well as to compare kinase requirements between primary and metastatic cancer cells.

He told SciBX the findings from the PNAS papers are neither patented nor licensed.

Moy, B. SciBX 1(39); doi:10.1038/scibx.2008.941

Published online Oct. 30, 2008

\section{REFERENCES}

1. Grueneberg, D. et al. Proc. Natl. Acad. Sci. USA; published online Oct. 20, 2008; doi:10.1073/pnas.0808019105

Contact: Ed Harlow, Harvard Medical School, Cambridge, Mass. e-mail: eharlow@hms.harvard.edu

2. Baldwin, A. et al. Proc. Natl. Acad. Sci. USA; published online Oct. 20, 2008; doi:10.1073/pnas.0806195105

Contact: Ed Harlow, Harvard Medical School, Cambridge, Mass. e-mail: eharlow@hms.harvard.edu

3. Bommi-Reddy, A. et al. Proc. Natl. Acad. Sci. USA; published online Oct. 20, 2008; doi:10.1073/pnas.0806574105

Contact: Ed Harlow, Harvard Medical School, Cambridge, Mass. e-mail: eharlow@hms.harvard.edu

4. Grueneberg, D. et al. Proc. Natl. Acad. Sci. USA; published online Oct. 20, 2008; doi:10.1073/pnas.0806578105

Contact: Ed Harlow, Harvard Medical School, Cambridge, Mass. e-mail: eharlow@hms.harvard.edu

5. Zheng, L. et al. Proc. Natl. Acad. Sci. USA 101, 135-140 (2004)

6. Paddison, P.J. et al. Nature 428, 427-431 (2004)

7. Berns, K. et al. Nature 428, 431-437 (2004)

8. Kolfschoten, I.G. et al. Cell 121, 849-858 (2005)

9. Westbrook, T.F. et al. Cell 121, 837-848 (2005)

10. Moffat, J. et al. Cell 124, 1283-1298 (2006)

COMPANIES AND INSTITUTIONS MENTIONED

Ambit Biosciences Corp., San Diego, Calif.

Brigham and Women's Hospital, Boston, Mass.

Daiichi Sankyo Co. Ltd. (Tokyo:4568; Osaka:4568), Tokyo, Japan

Dana-Farber Cancer Institute, Boston, Mass.

GPC Biotech AG (Xetra:GPC; NASDAQ:GPCB), Munich, Germany

Harvard Medical School, Boston, Mass.

Kinaxo Biotechnologies GmbH, Martinsried, Germany

Max Planck Institute of Biochemistry, Munich, Germany

Pfizer Inc. (NYSE:PFE), New York, N.Y. 